\title{
The Role of Private Security Service Providers in Crime Prevention; A Study of Lurambi Sub-County, Kenya
}

\author{
Ahmed Kassim Wangara \\ Department of Criminology and Social Work \\ Masinde Muliro University of Science and Technology \\ P.O Box 190 - 50100, KAKAMEGA, KENYA \\ Dr. Evans M. Oruta \\ Department of Criminology and Social Work \\ Masinde Muliro University of Science and Technology \\ P.O Box 190 - 50100, KAKAMEGA, KENYA \\ Prof. Kennedy Bota \\ School of Education \\ Masinde Muliro University of Science and Technology \\ P.O Box 190 - 50100, KAKAMEGA, KENYA
}

\begin{abstract}
This study aimed to examine the role of private security providers in crime prevention in Lurambi Sub-County, Kenya. The study was necessitated by private security providers' presence and use to protect life, property, and maintenance of law and order in Lurambi Sub-County, Kakamega County, Kenya. The Routine Activity and Situational Crime Prevention Theories of criminology informed the study. Specifically, this study intended to establish resource availability for private security service providers in crime prevention in Lurambi Sub-county, Kenya. The study adopted descriptive and correlational research designs. The primary target population constituted 358 respondents, both male and female, drawn from six registered and regulated private security service providers in Lurambi Sub-County, 5 senior police officers in charge of security, police administration, and 4 police stations across Lurambi Sub-County, and 133 clients of private security services. Purposive sampling was used to identify the 6 registered and licensed private security firms which provided the study population. Proportionate sampling with a statistical framework of $30 \%$ was used to identify 108 private security service providers who formed the sample size to ensure that the private security officers from the 6 firms were represented in the same proportion that they existed within the population. Questionnaires were used to collect data from three groups of respondents, including 108 private security officers, 6 managers each in charge of each private security firm that participated in the study, and 40 clients sampled from the 6 private security firms that participated in the study. Interview guides were used to collect data from 5 senior police officers in charge of security, police administration, and 4 police stations spread across Lurambi Sub-County. Study findings revealed that private security service providers in Lurambi Sub-County did not possess adequate resources needed to prevent crime. The study recommended that private security service providers should consider deploying adequate resources to strengthen crime prevention efforts.
\end{abstract}

Key Terms: Private Security, Resources Availability, Crime Prevention

DOI: $10.7176 /$ PPAR/11-6-05

Publication date:July $31^{\text {st }} 2021$

\subsection{Background of the Study}

Before outlining security, it is essential to analyze the need and the importance of security to human civilization. This redirects us to Maslow's hierarchy of needs, a theory advanced by Sir Abraham Maslow in 1943. According to Mkilindi (2014), the theory opines that, as human beings meet the most basic needs, they tend to have an insatiable desire to satisfy higher needs in relation to the hierarchy of needs proposed by Maslow. The most important need at the base of the hierarchy includes physiological needs such as food, water, and shelter. The second most important category is generalized as security which includes, the need to have a safe and secure environment. The concept of both the private and public security industry aims to meet and actualize this need. This outlines the importance of safety and security in human civilization.

Fischer, Halibozek, and Walters (2012) defined security as a predictable habitation where an individual or a group of people may achieve their dreams without fear of being disrupted, injured, or killed. From the above perspective, security can be associated with a sense of being free from fear of disruption, injury, or any deliberate activity that may disrupt one from attaining their goal. George and Kimber (2014) opine that it is difficult to define the concept of private security based on the existence of different variations in defining the term "security" itself, from which the idea of private security originates from. Nevertheless, several scholars 
have attempted to develop definitions for private security, even though most of them have provided definitions that suit their own perspectives and interests. Nsibambi (2014) defined "private security" as security and any related services being provided by any other entities apart from the government directed towards preventing crime.

According to Nemeth (2012), the concept of Private security in continental America followed the same patterns as Medieval England. The need for the colonial settlers from England to protect themselves from threatening hostilities and attacks from the native red Indians and other colonial powers such as the Spanish resulted in the formation of watch groups. The first documented one dates back to 1634 in Boston. The need for security watch services made it mandatory for all males above 18 years to be enlisted in active night watch duties to ensure maximum security for the forts. Later on, this new trend in security took a commercialization trend with the formation of Pinkerton Company in Chicago by Allan Pinkerton, which later became the most prominent Private Security firm in the world.

Berg and Howell (2017) opine that South Africa provides the best trajectories for studying private security since they have the best experiences in implementing private security as a practice. They argue that the private security industry in South Africa grew rapidly between the 1970s and early 1980s due to anti-apartheid revolts since most policing efforts were directed towards quelling the revolts. There was increased crime and anarchy; thus, private security service providers had to be allowed to bridge this gap. Currently, many private security service providers are operating in the country. According to Kasali (2011), the consumption of services provided by Private security service providers is not considered a strange phenomenon in Nigeria. In the pre-Colonial Nigerian culture, the traditionally rich ancient times often required private guards' services to protect their households against physical attacks.

Kenya, as a developing country, enjoys a rich history of private security with the first private security companies, including KK Security (Currently known as Guard a world), Securicor Kenya (Currently operating as G4S), and factory guards (Currently operating as Security Group) being in existence in the country since the early 1960s before the country gained independence (Abrahamsen \& Williams, 2011). The above perspective proves that private security is not new or rather did not start with the economic recess in the early 1990s. Private security companies were in existence even before the country gained independence from the British in 1963. However, Ngari (2015) notes that the exact number of private security service providers operating within the country cannot be established because there was little to no industry regulation since most private security companies were registered as private limited companies and still operate as such.

\subsection{Statement of the Problem}

The state law enforcement has the overall responsibility of providing security and preventing crime within the society based on the analogy that they are the primary custodians of criminal law and at the same time collect taxes from the citizens to meet the costs of the same purpose. The problem is despite the consistent presence and existence of state-provided law enforcement agencies, including the national police service, the County enforcement units and other quasi-police units, there has been an enormous increase in the presence and use of private security service providers in preventing crime and managing public safety in Lurambi Sub-County, Kenya. A keen review of most commercial, residential, and public spaces depicts private security service providers as the key players in crime prevention despite the presence of state law enforcement agencies who ought to provide such services as part of the social welfare services to which they are paid to provide. Karuri and Muna (2019) state that previous studies conducted in Kakamega County, including Lurambi-Sub County, have focused on law enforcement and community policing, deliberately omitting other relevant stakeholders, including private security service providers who are ever-present and persistently contributing to crime prevention. They also argue that previous studies have focused on specific security programs, including community policing and the Nyumba Kumi Initiative, leaving out the crime prevention aspect of them. This necessitates more in-depth studies on private security service providers, their role and their impact on crime prevention in Lurambi Sub-County, Kenya.

\subsection{Research Objective}

Establish resource availability for private security service providers in crime prevention in Lurambi Sub-County, Kenya

\subsection{Research Questions}

What are the resources available for private security service providers in crime prevention?

\subsection{Justification of the Study}

For years, private security service providers have been stakeholders in providing security and public safety services despite the presence of state law enforcement agencies. However, despite the presence of private 
security service providers, less is known about their activities, resources, levels of training, and whether there exist any collaboration programs between them and other security stakeholders, and more importantly, their effect on crime prevention.

\subsubsection{Philosophical justification}

There is a complimentary relationship between the existence of private security service providers and crime prevention in Africa as a continent and the rest of the world. However, most scholars tend to concentrate their studies on other stakeholders in crime prevention at the expense of private security (Karuri \& Muna, 2019). Private security service providers are significant stakeholders in crime prevention because they supplement the state-provided law enforcement by providing specialized security services for their clients whose security needs cannot be met by the state. Their presence in private and public spaces institutes reduced the fear of crime and adversely reduced the risk of criminal victimization. Without such studies, it will be extremely difficult to understand their contribution to crime prevention.

\subsubsection{Academic Justification}

The findings of this study are regarded as necessary based on the fact that it will help provide additional knowledge in criminology, criminal justice, and security studies. According to Button (2019), there has been an enormous increase in academic research, study courses, and peer-reviewed publications about state-provided law enforcement, which paints them as the only entities involved in crime prevention and ensuring public safety. A keen review of existing literature on crime prevention may result in one developing this conclusion. However, in reality, many other agents contribute towards crime prevention, including private security service providers. This proves that the study will contribute to existing knowledge.

\subsubsection{Policy justification}

Policymakers in the security sector can use this study to formulate policies that will improve the contribution and role of private security service providers in crime prevention because it has an empirical basis. The findings may also be utilized in making amendments and formulating more policies to support the efficiency of the Private Security Regulatory Act (2016), specifically in the sub-sections involving resources held by private security service providers, training, and cooperation. These will also go a long way in supporting the vision 2030 , the big four agenda, and the millennium development goals indirectly because it supports the national and global realization of a crime-free society.

\subsection{Literature Review}

This section analyses this subject's existing literature by examining current studies sustaining or opposing this research

\subsubsection{Introduction to Security and Private Security}

According to Bamidele et al (2016), security is an inevitable phenomenon of human life. As human beings continue to live and socialize together, security becomes more of a necessity than a luxury. This redirects us to Maslow's hierarchy of needs, a theory advanced by Sir Abraham Maslow in 1943. According to Mkilindi (2014), the theory opines that, as human beings meet the most basic needs, they tend to have an insatiable desire to satisfy higher needs in relation to the hierarchy of needs proposed by Maslow. The most important need at the base of the hierarchy includes physiological needs such as food, water, and shelter. The second most important category is security which includes, employment, resources, and the need to have safety and security. The concept of both the private and public security industry aims to meet and actualize this need. This outlines the importance of safety and security in human civilization. From the above statement, it can be deduced that security is almost a part of nature.

According to George and Kimber (2014), there is no standard definition for the term "security" based on the fact that there are different variations in the same definition. However, several notable scholars in the field of safety and security have attempted to come up with different definitions in a variety of senses to bring about a variety of meanings. Fischer et al (2012) defined security as a predictable habitation where an individual or a group of people may achieve their dreams without fear of being disrupted, injured, or killed. From the above perspective, security can be associated with the physical aspect and the psychological sense. It is a combination of a good state of mind supported by a peaceful environment conducive to an individual to actualize their goals.

According to Franke and Von (2011), any act involving putting up deliberate measures to prevent a security or a criminal risk from happening qualifies to be referred to as crime prevention. This is based on the analogy that crime prevention is proactive rather than reactive. Franke and Von (2011) further opine that, even though the State may manifest itself as a monopolist in providing security and related services, they are not the only entities within the society involved in such a great course. The above statement indeed reaffirms that even though security may manifest itself through different perspectives, the government is not the only institution engaged in crime prevention and the provision of security-related services. It proves that security, just like many other activities, may also be commercialized or privatized.

According to Abrahamsen and Williams (2016), the commercialization of security, which was previously, a 
social welfare system funded by the State, has aroused a lot of interest worldwide in recent years. The debates on the use of private military contractors, also known as the dogs of war and mercenaries, have not escaped the public limelight. This has shaped the growth of private security industries. The statement above proves that the provision of security and related services was purely a State affair until recently. Private security is a new phenomenon that is taking shape in postmodern society.

Nsibambi (2014) defined "private security" as security services provided to clients by non-State agencies. He cited that the growth of private security in most parts of Africa has been propelled by governments' lack of sufficient capacity and funds to provide proper security to the citizens. He used South Africa and Uganda's case that he cited as a case study representing many other African countries ranked as the third world and struggling in funding the basic social welfare programs. From this approach, it can be deduced that any security and related services being offered by any other entity rather than the State qualified to be labelled as private security. This is based on the fact that the provision of security is considered one of the core functions and the characteristics of a government from the earliest eras of monarchs to the modern times when democracy is the order of the day.

George and Kimber (2014) argue that the concept of Private security existed much earlier than most of the global governments and empires. They argue that the first attempts of private security can be derived from the deliberate attempts and activities of early and less civilized individuals to protect their land and families from potential threatening dangers and hostilities. However, this narrative can be disputed because, at such a time, the concept of government had not yet existed. Thus, the institutionalization of security as one of the core functions of government was not yet realized.

Going back to the annals of history, Dempsey (2010) sheds light on the earliest documented circumstances in British England that necessitated the origin and the establishment of Private Security. The advent of this enterprise was catalyzed by increased crime in rural England in the early eighteenth century, which prompted the rich to recruit private individuals who mostly included gamekeepers to secure their properties on their behalf. Simultaneously, the rich provided security back up to their guards by sleeping within the same establishment with their weapons ready to help repulse any form of threat, hostility, or even danger that might be lurking around. They later formed security associations and established collaborations in a bid to gain more strength and resilience. From my perspective, it is essential to note that a government was in existence during this period. However, the wealthy citizens took it upon themselves to provide security for their households and properties. The existing government did not take any part in this arrangement. From then, the concept of Private security became the norm globally.

According to Fischer et al (2012), there were programs in medieval England to clear bushes and any other natural vegetation from the king's roads that provided a haven for criminally minded individuals and their associates to hide and launch attacks on innocent, unsuspecting road users. In order to protect the subjects from the debilitating effects of crime at night, there were also night watchmen employed and assigned by the royals to prevent crime strategically. These acts were precautionary and may be considered as ancient crime prevention mechanisms. This is based on the premise that they were planned activities directed towards lowering the risk of crime from happening, no matter how simple or primitive it is, can be regarded as crime prevention. According to Ekblom (2010), crime prevention can be defined as any mechanism put in place to reduce the probability of a crime happening. This includes all the activities that are proactive in nature. This statement proves the fact that any deliberate activity that tries to reduce the chances of a criminal act from happening can be regarded as crime prevention. As long as it is proactive in nature rather than reactive after a crime incident has been reported.

According to Nemeth (2012), the concept of Private security in continental America followed the same patterns as Medieval England. The need for the colonial settlers from England to protect themselves from threatening hostilities and attacks from the native red Indians and other colonial powers such as the Spanish resulted in the formation of watch groups. The first documented one dates back to 1634 in Boston. The need for security watch services made it mandatory for all males above 18 years to be enlisted in active night watch duties to ensure maximum security for the forts. Later on, this new trend in security took a commercialization trend with the formation of Pinkerton Company in Chicago by Allan Pinkerton, which later became the most prominent Private Security firm in the world. Its growth was catalyzed by the claims that they protected Sir Abraham Lincoln from an assassination attempt.

According to Strom et al (2010), Private security industries are an essential component of security and safety in the United States and abroad today since private security is responsible not only for protecting many of the nation's institutions and critical infrastructures systems but also for protecting intellectual property and sensitive corporate information. From the above statement, it can be deduced that since the United States is one of the world's most developed countries, the fact that they have allowed private security to secure most of their critical infrastructure proves the fact that they have the capacity and the resources to prevent crime. In order for the State to trust private entities with critical infrastructure, the private sector has to prove to the State that they have the capacity and the resources needed to secure and maintain the infrastructure. This also applies to Kenya, where many key parastatals have contracted private security service providers to secure their facilities despite 
being state entities with the ability to request security directly from the government.

According to Abrahamsen and Leander (2016), the expansion of private security as a form of business has grown rapidly worldwide and in Africa. The same perspective is advanced by Gumedze (2010), who argues that South Africa provides the best trajectories for studying private security since they have the best experiences in implementing private security as a practice. According to Berg (2010), the private security industry in South Africa grew rapidly between the 1970s and early 1980s when the South African law public enforcement agencies diverted their attention from the primary policing duties to concentrate on quelling revolts that resulted from the anti-apartheid campaigns that were being advanced by the majority black. They had to do this to contain the high political temperatures as this period was the height of the heat of several anti-apartheid campaigns. To prevent further anarchy, the South African Apartheid government had no option but to allow the private security companies to bridge the gap. Currently, most private security service providers operating in the country possess relevant training, knowledge, skills, and experience in military science, intelligence gathering, criminology, and basic police training

Singh (2016) argues that the South African Police are only about a third of Private Security Service Providers, which relatively increases one's probability of consuming Private Security Service Providers' services rather than the police. This trajectory is significantly influenced by aspects such as the market forces of demand and supply and the specific individual security needs brought in the specialization concept in terms of service provision among Private Security Service Providers.

According to Kasali (2011), the consumption of services provided by Private security service providers is not considered a strange phenomenon in Nigeria. In the pre-Colonial Nigerian Culture, the traditionally rich of ancient times often required the services of PSSPs to protect themselves, their families, and properties against the misconduct and the threats brought about by the existence of social misfits in their midst. The emergence of colonial rule failed to completely wipe out this tradition since newly installed elites still required Private Security Service Providers' presence. The colonial administration had brought about radical change, but the curse and social misfits' presence had remained constant in the equation. Generation to generation, they continued to wreak havoc through social misconduct. At the time, the private security service providers in operation were still unregistered and untrained and lacked the legal and professional framework needed for their regulation and operation. The definition of a Private Security Service Provider had taken an uncivilized perspective. For instance, it failed to draw distinct boundaries between occupation and practice. The quark services of powerful and brave hunters could be sought after, consumed, confused, and used interchangeably with the term "Private security."

According to Diphoorn (2016), the emergence of private security in Kenya was connected to the government's failure to provide security, which was common in the late 1980s and continued through the 1990s. The consequences of economic decline had affected Kenya and the rest of Africa, resulting in drastic cuts in State expenditure and investments to meet donor expectations, such as the Structured Adjustment Program imposed by the International Monetary Fund. Thus, most State corporations were privatized, and administrative roles were reorganized to cut spending due to their inability to provide essential services and sustain their own operations. This pushed the majority of unemployed citizens into engaging in crime and illegal activities to survive. Diphoorn (2016) further opines that this increased both the levels and the fear of crime, necessitating the emergency and growth of Kenya's private security industry. Simultaneously, the country was characterized by rampant corruption, mismanagement of public funds and assets, and failure to provide employment opportunities to the growing pool of unemployed youth who were a risk factor for insecurity.

Kenya, as a developing country, enjoys a rich history of private security with the first private security companies, including KK Security (Currently known as Guard a world), Securicor Kenya (Currently operating as G4S), and factory guards (Currently operating as Security Group) being in existence in the country since the early 1960s before the country gained independence (Abrahamsen \& Williams, 2011). The above perspective proves that private security is not new or rather did not start with the economic recess in the early 1990s. Private Security Companies were in existence even before the country gained independence from the British in 1963.

However, Ngari (2015) notes that the exact number of private security service providers operating within the country cannot be established because there was little to no regulation of the industry since most private security companies were registered as private limited companies operate as such. However, through the Ministry of Interior and coordination of the National Government, the Government of Kenya has recently made great strides towards regulating the industry after President Uhuru Kenyatta signed the Private Security Regulatory act in May 2016. This is proof enough that the government is committed to implementing the recommendations of The United Nations Guidelines for the Prevention of Crime of 2010. The guidelines offered advisory that the State and the corporate sector should work together to prevent crime. In this sense, private security service providers are one of the key players in the corporate sector. This was also indicated in the note by the Secretariat on civilian private security services. This proves that private security service providers have a noble role to play in crime prevention and community safety. VanSteden (2011) proposes that citizens in exercising self-security 
should put up measures to protect themselves and their properties against potential harm and risks by contracting private security service providers at their own will and cost. This proves that citizens have a right to hire or contract private security service providers to meet their specialized security needs. It further proves that personal security is not entirely the State's duty but a collective responsibility involving a number of stakeholders, including private citizens. Private security is indeed one of the consequences of the individual's right to make choices in relation to their own personal security.

Daily security returns filed by various private and public law enforcement agencies worldwide prove that crime is a social phenomenon that cannot be made extinct to totality. This again proves that the presence of private security service providers is necessary rather than an option. This echoes the sentiments expressed by Emile Durkheim, who argued that crime is a normal part of a functioning society (Abubakar, 2019).

Abrahamsen (2010) opines that the growth of private security to citizens and properties has been catalyzed by the rapid evolution of science and technology, regional markets, and demographic factors such as population increase, which affected many countries in the $20^{\text {th }}$ century. Governments have had to initiate laws and policies to suit this situation, with Kenya enacting the Private security regulatory Act (2016) and the Cyber Crime Act (2018). The lack of a legal framework to handle and prosecute these crimes depicts the reality that most governments were neither prepared nor had the capacity to handle such crimes. Thus most systems have to rely on the private sector for such services; therefore, the emergency of private security.

According to Heinecken (2014), Private security affects a number of development-related factors, such as the capacity of States to govern, overall feelings of public safety, economic growth, and social welfare. As mentioned earlier, governments have a primary duty of protecting their people and their properties. Accordingly, Private Security Companies (PSCs) play an essential role in preventing crime and enhancing community safety.

Ortmeier (2017) also notes that some Private security operations around the globe including; patrolling public streets, transporting valuables, protecting critical infrastructure, providing security at airports and other major public transport hubs, responding to alarm activations, conducting surveillance, securing order and dealing with crowds at large public events, and investigating crimes. The civilian private security industry usually assumes the primary role in providing crime prevention and community safety.

According to Shaw (2010), the United Nations Guidelines for the Prevention of Crime proposes that government institutions, all segments of civil society, and the corporate sector should work together to prevent crime. As indicated in the note by the Secretariat on Civilian private security services, these services have a role in crime prevention and community safety.

The rate of expansion of private security companies dwarfs that of private military companies. Similarly, while their concentration on the more mundane aspects of security such as guarding, electronic alarm systems, patrolling, risk analysis, and management may lack the eye-catching cachet of the new 'corporate dogs of war,' they have a profound impact on the day-to-day provision and politics of security. Private security companies' growth has significantly altered the security landscape both locally and globally, leading to and reflecting an increasing commoditization and politicization of security (Abrahamsen \& Williams, 2015).

\subsubsection{Resources available for Private Security Service Providers in Crime Prevention.}

Argote (2012) suggests that resource availability is one of the primary conditions that any entity must fulfil to be effective in its goal. The resources must be valuable and relevant to the assignment and objectives of the firm. Private Security service providers are business entities. To generate profits and meet the market demands, they need to possess and maintain relevant resources in terms of equipment and personnel. This is also one of the requirements of the regulatory framework that governs its operations in Kenya. However, most private security service providers in Africa, Kenya, included operate as quarks without relevant training, equipment, and, worst of all, regulation.

According to Strom et al (2010), the private security industry is an important entity that proves security and safety in both the United States and abroad. In the modern world, they are accredited for providing both physical and information security to millions of people across the globe. From the above statement, the fact that private security provides a security solution to millions of people around the world sets the need for them to be adequately equipped in terms of equipment, funding, and well skilled and experienced personnel in order for them to be more effective in terms of preventing crime and ensuring public safety. The State must also consider the same before delegating security duties to private security service providers.

Smith and Brooks (2012) argue that most governments have been incapacitated by the lack of resources and cannot guarantee total security to their citizens. This statement can be proved by high crime rates being witnessed, especially in third world countries in parts of Africa and Asia that are grappling with low per capita income. Most African governments are incapable of providing essential commodities and services, including water, healthcare, and security. Most heavily rely on donor funding. Therefore individuals have no alternative but to seek complementary services from private entities to secure themselves and their households.

This perspective had earlier been brought to attention by Dambazau and Rtd (2013), who argued that individuals have employed alternative programs to complement the State provided and funded social welfare 
programs to contain crime as a social menace. The complementary programs include access control, installing surveillance cameras, and even physical surveillance mechanisms such as private patrols. Private security service providers provide such services.

\subsubsection{The concept of crime prevention and private security}

There is no standard widely accepted definition for the term "crime prevention." Several scholars in criminology and security studies have attempted to define it in a variety of senses to bring about a variety of meanings. According to Blevins (2018), the National Crime prevention institute recommended the definition of crime prevention as "the expectation, recognition, and admission of potential security or crime risk and the measures put in place to eliminate it. In the perspective of private security, most clients employ private security services based on the expectation of a perceived security risk and recognition that if the risk occurs, it will result in inevitable consequences. Private security is thus one of the measures put into eliminating this risk. Therefore, it is correct to note that private security somehow contributes to crime prevention.

According to Ekblom (2010), crime prevention can be defined as any mechanism put in place to reduce the probability of a crime happening. This includes all the activities that are proactive in nature. This Statement proves the fact that any deliberate activity that attempts to reduce the chances of a criminal act from happening can be regarded as crime prevention as long as it is proactive in nature rather than reactive.

Wilson and Petersilia (2010) argue that crime prevention should be defined not according to the intentions of the deliberate activity but according to its consequences. If an activity is well coordinated in such a manner that the end may prevent a crime from happening, it qualifies to be termed as crime prevention. The same can be attributed to the activities of private security service providers.

As opined by Hollis-Peel et al (2011), Cohen and Felson were the first to discuss the Routine Activity Theory, which explained the special circumstances required for a crime to happen. Later this theory was revised to suggest that for a criminal act to occur, three aspects must converge within the same space and time. The three aspects include a motivated offender, a suitable target or victim, and a potential guardian's absence. A motivated offender, in this case, may be anyone who may have any reason whatsoever to commit a crime. A suitable target might be any object worth stealing or a physical object that faces the risk of vandalism, or a person who faces the risk of victimization by the motivated offender. In this case, a potential Guardian might be any person whose presence may stop the crime incident from happening, including family members, police officers, neighbours, or Private Security Service Providers.

Private security service providers have also been portrayed as potential guardians by Carmola (2010), who opined that Private Security has the overall responsibility of controlling behaviour within a specific location such as a business establishment or public spaces with authority from the client. From the author's school of thought, it can be deduced that their presence alone is sufficient to psychologically dissuade a potential offender who may be motivated and harboring ill intentions of engaging in any form of misconduct against a target or a victim.

According to David (2011), any non-profit legal entity providing protective services to people, institutions, and facilities at a consensual fee to make a profit qualifies to be termed as such. The concept of protection is understood from the perspective of either crime or safety. David, (2011) further opines that according to the International Code of Conduct for Private Security Service Providers, Private Security is not allowed to use excessive force or firearms. Unless when under duress in circumstances that seek to prevent a serious threat to life. The amount of force repulsed in crime prevention should be proportional to the threat being emitted by the attacker or the circumstance. Any excessive force that exceeds the minimum proportion will be an infringement of professional ethics, international human rights, criminal law, or the terms and conditions provided by the regulatory framework.

\subsubsection{Theoretical Framework}

Criminologists study how, why, when, where, and under what conditions crime, criminality, and victimization occur (Barlow \& Kauzlarich, 2010). The concept and role of private security in criminology are majorly established under Becker's famous Routine Activity Theory in 1976.

\subsubsection{Routine Activity theory (RAT)}

According to Felson and Boba (2010), Cohen and Felson were the first scholars to discuss the Routine Activity Theory in 1979, which explained the special circumstances required for a crime to happen. Later this theory was revised to suggest that for a criminal act to occur, three aspects must converge within the same space and time. The three aspects include a motivated offender, a suitable target or victim, and a potential guardian's absence. A motivated offender, in this case, may be anyone who may have any reason whatsoever to commit a crime. A suitable target might be any object worth stealing or a physical object that faces the risk of vandalism, or a person who faces the risk of victimization by the motivated offender. In this case, a potential Guardian might be any person whose presence may stop the crime incident from happening, including family members, police officers, neighbors, or Private Security Service Providers.

Schneider (2014) opined that potential guardians might also include Private Security Service Providers who may have the overall responsibility of controlling behavior within a specific location, such as a business 
establishment with authority from the client. Barlow and Kauzlarich (2010) argue that the availability of crime opportunities plays a significant role in crime causation. For example, one cannot rob a bank without a chance to do so, which in this case is the existence of a bank. A crime opportunity presents itself through the availability of suitable victims and targets. These crime opportunities are concentrated over time and space. They depend on everyday movements and activities.

According to Leclerc (2014), private security firms usually employ a number of ways to implement the routine activity theory. They include increasing the effort of committing a crime through target hardening by installing electric fences and alarms at a fee. Leclerc (2014) further states that private security service providers implement the theory by increasing the risk of getting caught by installing CCTV Cameras for clients and conducting both on-site and remote surveillance on the client's property and other security needs. The same is also achieved by implementing another defense line, such as baggage screening and natural surveillance using guards.

According to Leclerc (2014), removing excuses is another form of crime prevention advanced by this theory. Private security service providers attain this by attaching their labels to their client's property, e.g., manned by BM Security, under CCTV surveillance, and many others. This is done to announce their presence and psychologically prepare any potential offender that they might have to be vetted and approved before accessing the private property, the client, or the target they are seeking to gain from. Leclerc (2014) argues that private security service providers prevent crime by concealing the possible target by conducting covert operations in cases involving high valued targets such as cash in transit. They also apply target removal and property identification by creating an inventory of the property and clients who have contracted them to provide their services. This guides them in the decision-making process to recruit and allocate strength in their various posts and branches (Leclerc, 2014).

As opined by Schneider (2014), the portrayal of private security service providers as potential guardians who have the overall responsibility of controlling behaviour within a specific location such as a business establishment with authority from the client and the State proves the existence of a relationship between this theory and the research topic. Even though the theory was adopted in this research, it is not perfect and has several shortcomings. Franklin et al (2012) point out the deficiencies of the theory, including the assumption that all offenders are rational human beings who can make rational decisions before engaging in criminal activities. Thus, it is not suitable to explain situations and criminal incidents involving offenders suffering from mental disorders who also pose a direct security risk to the public and themselves.

Therefore most offenders may not use or rather reason in the same rationale as the individual executing security mechanisms. Simultaneously, the theory focuses on preventing crime but does not focus on touch on how to rehabilitate offenders. Franklin et al (2012) further opine that the theory does not encourage empathy towards the victims of the crime because it paints the victim as careless through being unable to put up mechanisms to reduce their risk of victimization. The theory also calls for excessive surveillance, which may contravene civil rights, such as the right to privacy.

Based on the shortcomings of the theory mentioned above, the researcher supplemented it with a second theory, in this case, situational crime prevention theory of criminology, which he termed as sufficient to resolve the shortcomings of the first theory.

\subsubsection{Situational crime prevention theory}

Clarke (2017) opines that situational crime prevention is a significant theory in criminology, criminal justice, and security studies widely applicable in crime prevention. It advocates for the introduction of environmental and managerial changes that seek to reduce crime opportunities and the rewards obtained out of commission of the crime. Freilich and Newman (2017) argue that it focuses on proactive measures and methods towards crime through executing a preventive approach to eliminate crime opportunities. Unlike other theories in criminology, situational crime prevention focuses on existing circumstances within the environment that make it possible for a crime to occur and then, using in-depth analysis, develops the mechanisms to mitigate these circumstances. The mechanisms are aimed at reducing the opportunities and the rewards of crime. Freilich and Newman (2017) further note that situational crime prevention is among the few theories that can be applied beyond the current criminal justice system to support corporate and personal security efforts. According to Newburn (2012), situational crime prevention is widely applicable in law enforcement practice, administration, and management. Situational crime prevention is used in problem-solving policing, one of the major strategies applicable to policing worldwide. It focuses on a specific crime problem and the development of proactive mechanisms to resolve this crime problem.

According to Huisman and Van (2013), situational crime prevention emerged 45 years ago through merging ideas from other notable theories, including rational choice and opportunity structure theories.

Gruenewald et al (2015) opine that situational crime prevention best achieves crime prevention because it targets situational factors, thus making it impossible for the criminal act to be actualized irrespective of the offender's motivation by eliminating any possible factors that may arouse the offender's interest. Smith and 
Clarke (2012) outline the five crime prevention strategies advanced by Cornish and Clarke. Among them includes increasing the effort needed to commit crimes, increasing the risks of detection and getting arrested, reducing the rewards for committing crime, reducing provocations that lead to offending, and removing excuses for engaging in crime.

Smith and Clarke (2012) further allude that the risk of detection and getting arrested can be increased through extending guardianship on a property or a particular location which can be achieved physically through the use of private security service providers and electronically through the use of CCTV cameras which can be manned remotely by private security service providers. Others include natural surveillance, reducing anonymity cases within the physical environment, employing facility managers, and introducing electronic and remote surveillance. Clarke (2017) states that reducing the rewards of committing crime can be attained through concealing goods that may likely attract criminals, entirely removing them from plain view to reduce provocation, identifying properties through marking them and installing license plates on them. These activities can be undertaken by individuals or through contracting private security service providers who offer services, including engraving identity marks on properties, including tamperproof watermarks to protect brands against theft and concealment. Private security also does this by identifying and recovering stolen property.

Clarke (2017) further mentions reducing provocations as another strategy applicable in situational crime prevention. It includes individuals avoiding disputes, reducing provocation, neutralizing and repulsing negative peer pressure, and reducing imitation through brand protection efforts by private security companies dealing in brand protection and anti-counterfeit efforts.

Clarke (2017) concludes by noting the removal of excuses as the fifth strategy; however, it can be achieved through strictly adhering to laws, rules, and regulations and adhering strictly to security and safety rules and procedures. The regulations, security policies, and safety guidelines can be publicized through posters and any other publications. This will help create awareness concerning illicit and unwanted goods, resulting in easy enforcement of security rules and procedures by private security service providers in charge of the facilities.

\subsection{Research Methodology}

This study employed descriptive and correlational study research design. According to Creswell and Creswell (2017), the descriptive research design is commonly applied in studies that intend to describe and interpret the current status of individuals, settings, conditions, events, or a phenomenon as it exists within the society. The researcher has no intentions to manipulate the variables in order to influence the outcome. Creswell and Creswell (2017) further allude that descriptive studies are easier and simpler to conduct. They explain social phenomena as they naturally exist yet quite significantly provide a foundation upon which correlational and experimental studies emerge.

The study was carried out in Lurambi Sub-County of Kakamega County, Kenya. Lurambi Sub County hosts Kakamega town, which is the headquarters of Kakamega County. It is the second-largest county in Kenya (Wegulo, 2014). It is the regional headquarters of the larger Western Province. It lies 50 Kilometers North of Kisumu City at an altitude of 250-2000 meters. It has six wards, including Butsotso east, Butsotso south, Butsotso central, Shieywe, Mahiakalo, Shirere (Wegulo, 2014). It is an administrative, commercial, residential, industrial, and cosmopolitan set-up, making it prone to social problems such as crime (Wakhu, 2012).

. The target population consisted of private security officers, managers, and clients drawn from regulated and registered private security firms operating in Lurambi Sub-County Kenya and senior police officers of the national police service each in charge of police stations spread across Lurambi Sub-County.

The accessible population included 18 private security firms operating in Lurambi Sub-County. Purposive sampling was used to identify 6 private security service providers who participated in the study on the premise that they were the only private security firms that were fully registered, licensed, and permitted to operate and thus more willing to participate in the study hence providing the study population. According to Creswell and Creswell (2017), purposive sampling is a form of sampling where individuals are selected to participate in research based on a specific purpose. In this case, the 6 private security service providers were the only firms fully registered and licensed to offer private security services.

The target population involved 358 private security officers drawn from the 6 firms. Proportionate sampling with a statistical framework of $30 \%$ was used to identify 108 private security service providers who formed the sample size to ensure that the private security officers from the 6 firms were represented in the same proportion that they existed within the population. According to Creswell and Creswell (2017), proportionate sampling is a sampling method in which the researcher divides a finite population into sub-populations and then applies random sampling techniques to each subpopulation. Creswell (2014) explains that a sample of $20-30 \%$ of the accessible population is adequate for purposes of generalization of findings from the sample onto the entire population from which the sample was obtained. Simple random sampling was applied to identify respondents from each of the six firms.

Being descriptive research, the study involved assessing attitudes, opinions, and responses of Private 
Security Service Providers towards crime prevention. The researcher obtained permission from the University's School of Post Graduate Studies, the National Council for Science Technology and Innovation (NACOSTI), the County Director of Education, and the Ministry of education to comply with the regulatory framework governing research. The descriptive data was collected using questionnaires and interview schedules. The questionnaires for private security officers, the branch managers, and the clients for private security officers comprised both open and closed questions, which were preferred to take care of the illiterate respondents and who questionnaires posed a challenge. Interview schedules were used on the 5 senior police officers in charge of 4 police stations across Lurambi Sub-County. The questionnaires were filled and returned to the researcher. The researcher gained more control over the administered interview; hence bias recording was eliminated by obtaining clarifications when questions were not clearly were answered. According to Bryman (2016), more than one research tool can be used in descriptive research.

Data obtained from the field was edited and cleaned to ensure accuracy, completeness, and comprehensibility and coded for ease of analysis. Study data were analyzed using both descriptive and inferential statistics with the aid of the Statistical Package for the Social Sciences (SPSS) version 23 for windows. Descriptive statistics was computed to summarise and explain data and was presented in the form of frequencies, percentages, and mean. Inferential statistics included the Pearson product-moment Correlation Coefficient to measure relationships between variables and regression analysis to determine influences between and among variables. Qualitative data derived from open-ended questions was thematically presented in narrative forms and tables.

\subsection{Study Findings}

The study targeted 159 respondents, with 108 being private security officers, 40 private security clients, and 05 senior police officers commanding 4 police stations in Lurambi Sub-County. Out of the 159 identified for sampling purposes, 136 respondents were achieved with 89 private security providers, 6 were managers for private security firm managers, 36 private security clients, and 5 Senior National Police Service Officers. They participated in the study and returned data collection instruments. This gave the study a response rate of $81.76 \%$. According to Creswell and Creswell (2017), a response rate of more than $70 \%$ is enough to generalize findings from a sample onto the entire population from which the sample was drawn.

The study respondents comprised 106 (77.94\%) male and $29(21.32 \%)$ female respondents. With regard to the different sample categories, $89(65.92 \%)$ of the respondents were private security service providers, $6(4.41 \%)$ were managers for private security firms managers, 36(26.47\%) were private security service clients, and $5(3.67 \%)$ were senior police officers. Respondents were drawn from 6 private security companies, 25 business premises, 8 private residences, 3 learning institutions and, 3 police stations, all spread across Lurambi SubCounty.

\subsubsection{Influence of Resource Availability on Crime Prevention for Private Security Providers}

The objective of the study sought to investigate the influence of resource availability on the ability of private security providers to engage in crime prevention. To attain this data, the researcher used a standard questionnaire. 
Table 1: Findings from private security officers on resource availability on crime prevention

\begin{tabular}{|c|c|c|c|}
\hline & Available Resources & Yes & No \\
\hline 1 & Firm Branded protective Uniforms & $86(96.62 \%)$ & $3(3.37 \%)$ \\
\hline 2 & Condition of the Uniform( Standard \&Protective) & $2(2.24 \%)$ & $87(97.75 \%)$ \\
\hline 3 & Full body scanner metal detectors & $9(10.11 \%)$ & $80(89.88 \%)$ \\
\hline 4 & Hand held metal Detectors & $85(95.50 \%)$ & $4(3.56 \%)$ \\
\hline 5 & Protective Anti-Riot Gear & $55(61.79 \%)$ & $34(38.20 \%)$ \\
\hline 6 & Branded Security Patrol Vehicles & $22(24.71 \%)$ & $67(75.28 \%)$ \\
\hline 7 & CCTV Cameras & $27(31.46 \%)$ & $61(68.53 \%)$ \\
\hline 8 & Security Control Room & $58(65.16 \%)$ & $31(34.83 \%)$ \\
\hline 9 & Security/Emergency hot line & $71(79.77 \%)$ & $18(20.22 \%)$ \\
\hline 10 & Standby Alarm Response System and Team & $33(37.07 \%)$ & $56(62.92 \%)$ \\
\hline 11 & Client/Customer care Desk & $85(95.50 \%)$ & $4(4.49 \%)$ \\
\hline 12 & Established Office and physical address & $87(97.75 \%)$ & $2(2.24 \%)$ \\
\hline 13 & Trained Security Dogs/Canine Section & $38(42.69 \%)$ & $51(57.30 \%)$ \\
\hline 14 & Security Alarm Systems & $49(55.05 \%)$ & $40(44.94 \%)$ \\
\hline 15 & Fire engines/Firefighting Equipment & $21(23.59 \%)$ & $68(76.40 \%)$ \\
\hline 16 & Boom Barriers & $28(31.46 \%)$ & $61(68.53 \%)$ \\
\hline 17 & Automated Access Control System & $12(13.48 \%)$ & $77(86.51 \%)$ \\
\hline 18 & Client Based Customized Biometric System & $29(32.58 \%)$ & $60(67.41 \%)$ \\
\hline 19 & Shared resources with state law enforcement agencies & $36(40.44 \%)$ & $53(59.55 \%)$ \\
\hline 20 & If private security guards should be armed in the course of duty & $88(98.87 \%)$ & $1(1.12 \%)$ \\
\hline & Total & \multicolumn{2}{|c|}{$89(100.0 \%)$} \\
\hline
\end{tabular}

Study findings in table 1 reveal a picture of the adequacy of resources needed for private security firms to effectively provide crime prevention services to clients. Findings in Table 1 revealed that $89.88 \%$ of respondents did not have full-body scanners in their firms, which are essential access control equipment used to detect weapons and explosives. Lack of this equipment endangers the private security officers, their clients, and the general public, primarily when operating in commercial outlets. This negatively reduces their effectiveness in crime prevention. The study findings in table in table 1 further revealed that $97.75 \%$ of the private security officers who participated did not have standard protective uniforms, which are essential in reducing the exposure of private security service providers to workplace hazards which may include fire, attacks from criminals, and in some cases, protection from harsh weather conditions in the course of their duties in crime prevention. This reduces their effectiveness in crime prevention.

The study findings in table 1 revealed that $86.51 \%$ did not have automated access control systems, which effectively reduce the efforts used by security officers to manage and control access control, especially in facilities and institutions with motor vehicles and human traffic. This makes their work more difficult and tedious, which in turn reduces their effectiveness in preventing crime.

The findings in table 1 further revealed that $76.40 \%$ did not have firefighting equipment, which made it difficult for them to prevent arson and related crimes, thus limiting their efforts and effectiveness in crime prevention.

The study in table 1 further revealed that $75.28 \%$ did not have branded security patrol vehicles, which limited their effectiveness in responding to security emergencies, thus limiting their efficacy and efforts in crime prevention. The study in table 1 also established that $68.53 \%$ did not have CCTV cameras, making it difficult for them to conduct security surveillance to prevent crime. This affects their effectiveness and efficiency in crime prevention. The study in table 1 also established that $68.53 \%$ did not have boom barriers, making them less effective in managing access control for motor vehicles and trucks within facilities that they have been contracted to secure. This limits their effectiveness in conducting searches on all most vehicles that may access and leave their premises weapons, explosives, contraband, and in some cases, stolen property. This limits their efforts and effectiveness in crime prevention.

The study in table 1 further revealed that $67.41 \%$ of the respondents among private security service providers did not have a client-based customized biometric access system, which means that they are not able to restrict entry and exits in their clients' facilities, thus rendering their clients' facilities vulnerable to unauthorized access which increases the probability of criminal attacks. This limits their role in crime prevention. The study findings in table 1 also revealed that $62.92 \%$ of the private security interviewed did not have alarm response systems. This makes it difficult for them to call, receive and, in some cases, get alarm response services and somewhat back up in case of a security emergency or rather a criminal attack. This adversely limits their role in crime prevention.

The study in table 1 further revealed that $59.55 \%$ of the private security services providers who participated in the study believed that they do not share resources with State law enforcement agencies. This proves that most 
private security service providers do not have elaborate collaboration programs that facilitate sharing security resources between the private security service providers and the police, thus limiting their effectiveness in crime prevention. The findings in table 1 also revealed that $57.30 \%$ did not have trained security dogs. This limits their effectiveness in conducting searches, identifying contrabands and drugs, and protecting private security officers and their clients in case of an attack.

The study findings in table 1 , on the other hand, also revealed that $98.87 \%$ of respondents were of the view that private security guards should be armed with firearms while on duty to provide crime prevention services effectively. This proves that firearms are essential security resources for private security service providers because they will facilitate private security service providers in handling and neutralising armed criminals in private and public spaces, thus preventing crime. The findings in table 1 also revealed that $96.62 \%$ of respondents who participated in the study agreed that their organizations had firm branded uniforms which are useful in their identification by criminals, their colleagues, and most importantly, police officers. This will help them deter offenders from engaging in crime, as explained by the routine activity theory. The study findings in table 1 also established that $97.75 \%$ of the private security service providers who participated in the study agreed that they had an established office and physical address, which makes it easier for them to be physically contacted in case of a security emergency, in the course of inspection visits by officials from the Private Security Regulatory Authority to determine whether they are compliant to the Private Security Regulatory Act 2016 and by their clients. This increases their effectiveness in crime prevention.

The study findings in table 1 established that $96.6 \%$ had hand-held metal detectors that are important in conducting searches on walking pedestrians to detect any weapons and explosives, thus guaranteeing public safety and preventing crimes such as terrorism that is an emerging threat to global security. The study findings in table 1 revealed that $95.50 \%$ of the private security service providers had customer care desks, which are useful in handling client and public matters, including reporting criminal incidents and complaints regarding private security service providers' conduct.

The study in table 1 further established that $79.77 \%$ had emergency hotlines had security hotlines, $65.16 \%$ had security control rooms, $61.79 \%$ had protective anti-riot gear, while $55.05 \%$ had security alarm systems. These resources are necessary because they enable them to receive emergency calls from members of the public and clients in case of criminal attacks, security emergencies and, thus, help them respond promptly and swiftly and thus prevent crime.

Findings in Table 2 show descriptive analysis for responses to items on resource availability

Table 2: Descriptive analysis for responses by managers on who determines resources to avail for crime prevention

\begin{tabular}{lll}
\hline & What determines the Resources & Percentage \\
\hline 1 & The Company Board of Directors & $\mathbf{3}(\mathbf{5 0 . 0} \%)$ \\
2 & The client for the PSSPs Services & $\mathbf{2}(\mathbf{3 3 . 3 \%})$ \\
3 & The Private Security Regulatory Authority & $\mathbf{1}(\mathbf{1 6 . 6 \% )}$ \\
4 & The Private Security Officers & $\mathbf{0 ( 0 . 0 \% )}$ \\
5 & The Private Security Officers & $\mathbf{0 ( 0 . 0 \% )}$ \\
& Total & $\mathbf{0 6}(\mathbf{1 0 0 . 0} \%)$ \\
\hline
\end{tabular}

Managers for the sampled 06 private security firms were asked to indicate what determines the resources to avail for crime prevention. Findings in Table 2 revealed that $50.00 \%$ believed that the Company Directors determine the resources availed. This is true because the company directors determine the number of resources to invest in the company, including allocating resources towards crime prevention and procurement of security equipment. The Findings in Table 2 indicate that $33.33 \%$ of the managers who participated in the study believe that the client determines the resources to allocate to private security service providers for crime prevention. This is based on the fact that private security service providers shall allocate their security resources based on the nature of the assignment and the sum of the contract. In comparison, $16.66 \%$ were of the view that the Private Security Regulatory Authority determined the resources based on the provisions of the Private Security Regulatory Act 2016. This is because the Private Security Regulatory Act 2016 sets requirements for the specific resources that private security service providers should own. The findings below in Table 3 show descriptive analysis for managers' responses on what other resources should PSSPs be provided to enhance Crime Prevention. 
Table 3: Findings on responses by managers on what other resources should be provided to PSSPs to enhance crime prevention

\begin{tabular}{lll}
\hline & What determines the Resources & Percentage \\
\hline 1 & Patrol Vehicles & $\mathbf{2 ( 3 3 . 3 \% )}$ \\
2 & Firefighting Equipment & $\mathbf{1 ( 6 6 . 6 \% )}$ \\
3 & Ambulances for Emergency Evacuation & $\mathbf{1 ( 1 6 . 6 \% )}$ \\
4 & Surveillance Equipment & $\mathbf{1 ( 1 6 . 6 \% )}$ \\
5 & Comprehensive Medical Insurance Cover & $\mathbf{1 ( 1 6 . 6 \% )}$ \\
\multicolumn{2}{c}{ Total } & $\mathbf{0 6}(\mathbf{1 0 0 . 0} \%)$ \\
\hline
\end{tabular}

Managers for the sampled 06 private security firms were asked what other resources private security service providers should be provided to private security service providers to enhance crime prevention. The findings in table 3 revealed that $33.33 \%$ believed that private security service providers would effectively prevent crime when allocated patrol vehicles. Patrol vehicles are essential because they enable them to respond quickly to alarms and provide backup services in case of criminal attacks, thus preventing crime. Patrol vehicles also facilitate patrols within their jurisdiction and assignments, thus preventing crime. According to the findings in table $4.5,66.66 \%$ of the managers believe that provision of ambulances for medical emergency evacuation would enable private security service providers' work effectively. $16.66 \%$ of the managers believe that surveillance equipment's availability would significantly prevent crime. This is because it would enable private security service providers to carry out security surveillance, identify potential criminals, and proactively stop them before they attack. This would significantly impact on crime prevention. According to the findings in table $3,16.66 \%$ of the managers who participated in the study believe that provision of comprehensive medical insurance covers to private security officers would increase crime prevention efforts. This is based on the fact that most private security service providers refrain from confronting criminals due to the fear of getting injured in the absence of comprehensive medical insurance covers to pay their hospital bills if they get injured in the course of their duties.

\subsubsection{Findings for responses by Managers on the Resource Availability on Crime Prevention}

Findings in Table 4 shows the descriptive analysis of responses by managers of PSSPs to items on resource availability and crime prevention

Table 4: Descriptive analysis for responses by managers of PSSPs on the Resource Availability on Crime Prevention

\begin{tabular}{llll}
\hline & Available Resources & Yes & No \\
\hline 1 & $\begin{array}{l}\text { Do PSSPs have the necessary resources required to prevent crime } \\
\text { Do you think PSSPs should be armed }\end{array}$ & $\mathbf{2}(\mathbf{3 3 . 3 3 \% )}$ & $\mathbf{4 ( 6 6 . 6 6 \% )}$ \\
2 & & $\mathbf{5 ( 8 3 . 3 3 \% )}$ & $\mathbf{1}(\mathbf{1 6 . 6 6 \% )}$ \\
3 & $\begin{array}{l}\text { Do you share any resources with the National Police Service in } \\
\text { relation to Crime prevention }\end{array}$ & $\mathbf{5 ( 8 3 . 3 3 \% )}$ & $\mathbf{1}(\mathbf{1 6 . 6 6 \% )})$ \\
& $\quad$ Total & $\mathbf{0 6}(\mathbf{1 0 0 . 0} \%)$ \\
\hline
\end{tabular}

As shown in Table 4, 66.66\% of the managers responded that PSSPs do not have adequate resources required to prevent crime. $83.33 \%$ of the managers responded that PSSPs should be armed to more effective in preventing crime. This is based on the fact that private security service providers require sufficient resources to prevent crime. $83.33 \%$ responded that they do share resources with National Police Service in relation to crime prevention. They pointed out that among the resources, they include patrol vehicles, alarm systems, and even human capital during sensitive security operations such as logistics of high-valued and targeted goods for their clients. This negatively affects crime prevention because private security service providers do not have sufficient resources, as indicated in Table 4.

\subsubsection{Influence of Resource Availability on Crime Prevention for clients}

Findings in Table 5 show descriptive analysis for responses by clients to items on resource availability. 
Table 5: Descriptive analysis for responses to Resource availability

\begin{tabular}{|c|c|c|c|}
\hline & Available Resources & Yes & No \\
\hline 1 & Firm Branded Protective Uniforms & $34(94.44 \%)$ & $2(5.55 \%)$ \\
\hline 2 & Condition of the Uniform( Standard \&Protective) & $3(5.55 \%)$ & $33(94.44 \%)$ \\
\hline 3 & Full body scanner metal detectors & $1(2.77 \%)$ & $35(97.22 \%)$ \\
\hline 4 & Hand held metal Detectors & $26(72.22 \%)$ & $10(27.77 \%)$ \\
\hline 5 & Protective Anti-Riot Gear & $2(5.55 \%)$ & $34(80.55 \%)$ \\
\hline 6 & Branded Security Patrol Vehicles & $33(91.66 \%)$ & $03(08.33 \%)$ \\
\hline 7 & CCTV Cameras & $6(16.66 \%)$ & $30(83.33 \%)$ \\
\hline 8 & Security Control Room & $29(80.55 \%)$ & $7(19.44 \%)$ \\
\hline 9 & Security/Emergency hot line & $28(77.77 \%)$ & $8(25.00 \%)$ \\
\hline 10 & Standby Alarm Response System and Team & $11(30.33 \%)$ & $25(78.12 \%)$ \\
\hline 11 & Client/Customer care Desk & $30(83.33 \%)$ & $6(16.66 \%)$ \\
\hline 12 & Established Office and physical address & $33(91.66 \%)$ & $03(08.33 \%)$ \\
\hline 13 & Trained Security Dogs/Canine Section & $15(41.66 \%)$ & $31(86.11 \%)$ \\
\hline 14 & Security Alarm Systems & $30(83.33 \%)$ & $6(16.66 \%)$ \\
\hline 15 & Fire engines/Firefighting Equipment & $0(00.00 \%)$ & $36(100.0 \%)$ \\
\hline 16 & Boom Barriers & $2(19.44 \%)$ & $34(80.55 \%)$ \\
\hline 17 & Automated Access Control System & $6(16.66 \%)$ & $30(83.33 \%)$ \\
\hline 18 & Client Based Customized Biometric System & $11(30.55 \%)$ & $25(69.44 \%)$ \\
\hline 19 & Shared resources with State law enforcement agencies & $15(41.66 \%)$ & $21(58.33 \%)$ \\
\hline 20 & If private security guards should be armed in the course of duty & $32(88.88 \%)$ & $4(11.11 \%)$ \\
\hline & Total & \multicolumn{2}{|c|}{$36(100.0 \%)$} \\
\hline
\end{tabular}

Study findings in table 5 reveal a picture of the adequacy of resources needed for private security firms to effectively provide crime prevention services to clients. Findings in Table 5 revealed that $97.22 \%$ of the contracted PSSPs contracted by clients did not have full-body scanners in their firms, $94.44 \%$ did not have standard protective uniforms, $83.33 \%$ did not have automated access control, $100.0 \%$ did not have firefighting equipment, $8.33 \%$ did not have branded security patrol vehicles, $83.33 \%$ did not have CCTV cameras, $68.53 \%$ did not have boom barriers, $80.55 \%$ did not have a client-based customized biometric access system, $78.12 \%$ did not have alarm response, $58.33 \%$ of the clients were of the view that PSSPs do not share resources with State law enforcement agencies. In comparison, $86.11 \%$ did not have trained security dogs. On the other hand, study findings revealed that $88.88 \%$ of the clients believed that private security guards should be armed with firearms while on duty to effectively provide crime prevention services. However, $11.11 \%$ of the clients believed that PSSPs should not be armed since they may pose a security risk to the client himself. Arming the guards may increase their probability of becoming criminals. $94.44 \%$ of the clients opined that their guards had firm branded uniforms, $91.66 \%$ had an established office and physical address, $72.22 \%$ had hand-held metal detectors, $83.33 \%$ had customer care desks, $77.77 \%$ had emergency hotlines, $80.55 \%$ had security control rooms, $80.55 \%$ had protective anti-riot gear. In comparison, only $16.66 \%$ had security alarm systems.

\subsubsection{Influence of Resource Availability on Crime Prevention}

According to the findings obtained from the interview, one (20\%) of the interviewed senior police officers was of the view that private security service providers have the necessary resources required to prevent crime; however, four $(80 \%)$ of the senior police officers interviewed were of the view that private security service providers do not have the necessary resources needed to prevent crime. This is based on their interaction with the existing firms and their experience within the National police service. This is unfortunate because private security service providers require adequate resources, including human resources and equipment, to prevent crime.

According to the findings obtained by the study, $3(60 \%)$ of the senior police officers interviewed were of the view that private security service providers should be armed in the course of their duties. In comparison, 2 $(40 \%)$ were of the opinion that private security service providers should not be armed. In reality, private security service providers should be armed in the course of their duties because it will enable them to repulse attacks from armed criminals through the application of proportionate force.

According to the findings obtained from the interview by the study, $3(60 \%)$ of the senior police officer interviewed responded that they do share resources with private security service providers.

The most common resources shared were cited as motor vehicles, alarm systems, and communication equipment, especially in risky security assignments, including cash in transit. The 5 senior police officers in charge of police stations in Lurambi Sub-County were also interviewed on what resources they think private security service providers should be provided with to enhance crime prevention. 2 of them $(40 \%)$ were of the view that private security service providers should be provided with patrol vehicles. $3(60 \%)$ of the senior police officer interviewed responded that private security service providers should be armed in the course of their duties 
to be able to prevent attacks from armed criminals. In comparison, $2(40 \%)$ believed that private security service providers should be provided with surveillance and communication equipment to enhance their efforts in crime prevention. In reality, the equipment mentioned above and resources are essential because they increase private security service providers' capacity to prevent crime.

The Lurambi Sub-County Division Commander stated that "Private security firms are business entities owned by individuals. The availability of resources held by these firms depends on the amount of capital the investors are willing to sink into the business. The clientele served by the firm also dictates the availability of resources. Most of the time, we supplement their deficiency by providing backup services such as alarm response in security incidents. We also patrol in areas where they are assigned to ensure everything is running smoothly," Said the Kakamega Central Sub County Commander in whose jurisdiction Lurambi Sub-County lies (Field, 2019).

Officers from the national police service were engaged on a number of issues relating to resource availability for private security service providers in crime prevention in Lurambi Sub-County, Kenya. Findings interviews for senior police officers in charge of 4 police stations in Lurambi-Sub County have been analysed thematically and presented in the followings section.

Respondents were asked to comment on whether they think private security service providers have the necessary resources to prevent crime. The officer in charge of the Lurambi police post stated that most private security companies in Lurambi Sub-County do not have sufficient resources needed to prevent crime based on the analogy that most of them are private business ventures where owners invest minimum resources intending to make profits thus cannot risk investing a lot of resources. He further supported that private security service providers should be armed in their duties to have the capacity to prevent violent crime and protect themselves when under attack by armed criminals. He added that even though they share resources with private security service providers, the government should develop policies and guidelines that may make it possible for the two entities to share resources based on the fact that they both work towards a common goal of preventing crime. He stated that private security should be provided with patrol vehicles and weapon scanners to increase their efficiency in preventing terrorism and specifically in public spaces.

When asked whether private security service providers have sufficient resources, the officer in charge of the Shirere police post stated that private security service providers do not have the necessary equipment to prevent crime and, in most cases, have to depend on the backup provided by the police. "It is very common to spot armored cash in transit vehicle being provided with police escort. The same applies to many institutions requiring one or two police officers at their premises despite contracting private security service providers. This proves that they are inadequately equipped to prevent crime". Stated the senior police officer in charge of the Shirere police post. He further stated that Private security service providers share resources with police officers and, in most cases, police vehicles since most private security service providers lack enough patrol vehicles, limiting their capability on crime prevention. He added that "Private security service providers should be armed in the course of their duties to create general deterrence among potential violent offenders," Stated the officer in charge of the Shirere Police Post.

When asked as to whether private security service providers have the necessary resources to prevent crime, the officer in charge of the Ejinja Corner police post stated that some serious private security firms, especially multinational companies such as Group 4 Security and KK Security have the best security resources needed to prevent crime. However, local firms are ill-equipped, understaffed, and employ quarks to cut operating costs. He went ahead and suggested that private security service providers should be armed in the course of their duties to enable them to deter and repulse armed criminals. "Proliferation of small arms is one of the serious security challenges facing the county; therefore, to deal effectively with armed criminals and to prevent any form of violent crimes, private security service providers should be armed in the course of their duties." Stated the officer in charge of Shirere Police Post.

The officer commanding Kakamega Central police station stated that private security service providers do not have the necessary resources to prevent crime. He stated that most of them shun employing security specialists to cut down operating costs. "Most of the firms operating in Lurambi Sub-County are not licensed because they lack qualified staff. We will soon launch a crackdown to close them. I want to encourage clients to avoid contracting such firms since they are unprofessional and, in most cases, become a security threat to the client instead of protecting them. This is one of the reasons why I'm against arming of private security service providers". She said.

The Lurambi Sub-County police commander stated that private security service providers operating in Lurambi Sub-County do not possess the appropriate security equipment and resources outlined in the Private Security Regulatory Act (2016). He further stated that most cases involving theft reported by clients to the police could be prevented if only their contracted private security companies had sufficient and necessary equipment and resources to prevent crime.

'Private security service providers should not be armed in the course of their duties based on the fact that it 
would result in a sharp increase in cases of robbery with violence. This will further be complicated because most private security service providers are not adequately trained to handle and use these dangerous weapons. It will take Kenya years to actualize this," Stated the Lurambi Sub-County police commander.

These findings conform to the study by Thuranira and Munanye (2013), who opined that most private security service providers operating in Kenya do not have the necessary resources and equipment needed to prevent crime, limiting their efficiency in crime prevention. From the author's perspective, sharing existing resources between private security service providers and the national police service would significantly improve private security service providers' efforts and capability in crime prevention.

The findings also conform to the studies made by Kaguru \& Ombui (2014), who argue that the availability of resources is one of the significant factors that affect the performance of private security service providers based on the fact that it increases their efficiency in crime prevention. From the author's perspective, an increase in resources would significantly increase private security service providers' capacity to prevent crime.

The findings further conform to the study by Riunga (2019). They opine that the State should redesign the country's security architecture and plan to include the arming of private security service providers to increase their capacity in dealing with advanced cases of terror attacks within the city. This would increase private security service providers' capacity in preventing cases of violent crimes, including terrorism, thus proactively preventing terror attacks by neutralizing potential threats and, in this case, terrorists and any other violent criminals who may pose a threat to public safety. From the author's perspective, the terror attack on 16 January 2019 at Dusit D2 Hotel in Nairobi could have been avoided if private security officers who were manning the entrance would have been armed. They would neutralize the terrorists before they gain entry to the premises and killed 20 people.

Pearson Product Moment Correlation Coefficient was computed for the relationship between the availability of resources within private security providers and crime prevention in Lurambi Sub-County. The findings were presented in table 6

Table 6: Correlation Analysis between Availability of Resources and Crime Prevention

\begin{tabular}{llll}
\hline & & Resources & Crime Prevention \\
\hline Resources & Pearson Correlation & 1 & \\
& Sig. (2-tailed) & & \\
& $\mathrm{N}$ & 136 & 1 \\
Crime Prevention & Pearson Correlation & .681 & \\
& Sig. (2-tailed) & .000 & 136 \\
\hline
\end{tabular}

Source: Research Data (2019)

Study findings from correlation analysis depict a statistically significant and positive relationship between the availability of resources and crime prevention in Lurambi Sub-County $(\mathrm{r}=.681 ; \mathrm{P}<0.05)$. A positive correlation implies that an increase in the adequacy of resources results in increased private security firms' ability to provide crime prevention services to their clients. These results conform to previous studies' findings where resource availability relatively improved on crime prevention efforts in private security firms. Abrahamsen and Williams (2010) suggest that resource availability is one of the primary conditions a Private Security Service Provider must fulfill to effectively prevent crime. The resources must be valuable and relevant to the assignment and objectives of the Private Security Service Provider in relation to the client's specific security needs, government regulation, and the operating environment. They also argue that private security service providers' crime prevention efforts have directly influenced crime reduction in most geographical locations where they are operating. This proves that the availability of resources to private security would significantly improve their capacity in crime prevention. Shearing and Johnston (2013) note in the study conducted by a Rand Corporation for the US department of justice in 1985. The New York police had contracted the retail security officers to carry out arrests, hold suspects, confiscate contraband, and even record an incident and enter suspect's information into the police systems. To exercise these powers effectively, private security service providers have to be fully equipped. They must possess the relevant resources for them to play such a sensitive and crucial role. They were licensed to carry arms and other mutual resources. Previously, these resources had been a preserve of the police and other law enforcement agencies. In the post-modern world, private security service providers have been effectively equipped to prevent sophisticated forms of crime such as violent crimes, terrorism, and maintaining general public safety security.

Chinwokwu (2018) suggests that the availability of private security and their resources have made it easier for the governments to take credit for the fact that they have enough capacity to provide security within a certain geographical location. However, this is not true due to the fact that most citizens do not depend on Stateprovided security entirely. They have to recruit the services of private security service providers to bridge this gap. This has only been possible because private security service providers possess relevant security resources that have enabled them to meet the client's security needs effectively. State-funded law enforcement agencies 
and, in this case, the police have been unable to meet such demands due to the fact that they are understaffed, underfunded, and, most specifically, overstretched beyond their capacity. From the author's perspective, State law enforcement agencies being underfunded limits their ability in terms of resources needed to prevent crime. On the other hand, the fact that private security has been able to meet these needs proves that some, if not most, have the capacity to perform even better in preventing crime if allocated sufficient and relevant resources and equipment. The Private security regulatory Act (2016) provides the requirements for the relevant resources to be held by private security service providers in Kenya. The resources include security alarms systems to facilitate security back up in case of a security emergency, safes, vaults, secured containers all for safe storage of valuable goods, satellite tracking devices to enable them to keep track of their motor vehicles, personnel and in some cases, high target personnel. The Private security regulatory Act (2016) also proposes that private security service providers should possess surveillance equipment, closed-circuit television cameras (CCTV), intrusion detection systems in order to be able to carry out effective security surveillance, which is regarded as one of the proactive measures in crime prevention. The Act further stipulates that private security service providers must have intrusion detection systems, bomb detection equipment, fire detection systems, x-ray inspection systems, and many other detection equipment to easily detect weapons, bombs, and contraband goods proactively prevent crime within the public and private spaces. Private security service providers dealing in offering locksmith services are expected to have specialized devices to reproduce keys. At the same time, most private security service providers working in public spaces are required to have firefighting equipment to be able to able to prevent crimes related to Arson (Private security regulatory Act, 2016).

The regression analysis results where the availability of resources is used as a predictor for crime prevention are presented in table 7.

Table 7: Model Summary Adequacy of Resources

\begin{tabular}{llllll}
\hline & & & Std. Error of the \\
Model & $\mathrm{R}$ & R Square & Adjusted R Square & Estimate & Durbin-Watson \\
\hline 1 & $.029^{\mathrm{a}}$ & .173 & .014 & .91077 & 1.831 \\
\hline
\end{tabular}

a. Predictors: (Constant), Availability of Resources

b. Dependent Variable: Crime Prevention.

The study determined whether there was autocorrelation among Regressors through a calculation of the Durbin - Watson statistic. The statistic has to lie between1.5 - 2.5 (Garson, 2012). Durbin -Watson coefficient of 1.831 was established. Since the value was within the range of 1.5 and 2.5, there was hence no autocorrelation in the data residual. Thus, the linear regression model was appropriate for this study. Ogundipe, Idowu, and Ogundipe (2012), in their research, used Durbin - Watson test to determine whether there was autocorrelation in their data residuals. This justified the use of the regression model in their study.

Regression analysis was conducted to determine the amount of variation in crime prevention forms of delinquent behaviour explained by Authoritarian. The calculated $R$-value was 0.346 . $R^{2}$ value $=0.173$, which means that the availability of resources can explain $17.3 \%$ of the corresponding variation in crime prevention. The remaining $82.7 \%$ unexplained variance results from other factors that influence crime prevention that are not in the model. Such unexplained factors are accounted for by the stochastic error term. Study results from ANOVA for the availability of resources are presented in table 8 .

Table 8: ANOVA for Availability of Resources and Crime Prevention

\begin{tabular}{lllllll}
\hline Model & & Sum of Squares & Df & Mean Square & F & Sig. \\
\hline 1 & Regression & .174 & 1 & .174 & .196 & $.041^{\mathrm{a}}$ \\
& Residual & 246.362 & 297 & .830 & & \\
& Total & 246.536 & 298 & & & \\
\hline
\end{tabular}

a.Predictors: (Constant), Availability of Resources

b. Dependent Variable: Crime Prevention

A one-way analysis of variance (ANOVA) that provided information about levels of variability within the regression model and which formed a basis for tests of significance was used. ANOVA for the linear model presented in Table 8 for the availability of resources and crime prevention has an $F$ value $=0.196$, which is significant with a P-value $=0.041$, meaning that the overall model is significant in the prediction of crime prevention by private security firms in Lurambi Sub-County. The study, therefore, shows that the availability of resources has a significant influence on crime prevention and that availability of resources and is positively related to crime prevention.

\subsection{Conclusion}

Based on the empirical evidence, the following conclusion was made;

Study findings revealed a statistically significant and positive relationship between the availability of resources to private security service providers and crime prevention in Lurambi Sub-County. It is, therefore, concluded that the availability of resources increases the levels of crime prevention. 


\subsection{Recommendations}

In light of the findings and conclusion made, the study recommends that Private security service providers should consider deploying adequate resources to bolster their efforts in crime prevention. The resources may include trained personnel, Patrol vehicles, surveillance equipment, among many other resources as outlined and regulated by the Private Security Regulatory Authority

\section{REFERENCES}

Abrahamsen, R., \& Leander, A. (Eds.). (2016). Routledge handbook of private security studies. Routledge, Taylor \& Francis Group.

Abrahamsen, R., \& Williams, M. C. (2011). Security privatization and global security assemblages. The Brown Journal of World Affairs, 18(1), 171-180.

Barlow, H. D., \& Kauzlarich, D. (2010). Explaining crime: A primer in criminological theory. Rowman \& Littlefield.

Berg, J. (2010). Seeing like private security: evolving mentalities of public space protection in South Africa. Criminology \& criminal justice, 10(3), 287-301.

Berg, J., \& Howell, S. (2017). The private security complex and its regulation in Africa: Select examples from the continent. International Journal of Comparative and Applied Criminal Justice, 41(4), 273-286.

Blevins, K. R. (2018). Crime Prevention. The Handbook Abrahamsen of Social Control, 181-193.

Button, M., \& Stiernstedt, P. (2018). Comparing private security regulation in the European Union. Policing and Society, 28(4), 398-414.

Buzatu, A. M. (2015). Towards an International Code of Conduct for Private Security Providers (p. 61). Ubiquity Press.

Buzatu, A. M., \& Buckland, B. S. (2015). Private military \& security companies: Future challenges in security governance. Geneva Centre for the Democratic Control of Armed Forces.

Carmola, K. (2010). Private Security Contractors and New Wars: Risk, Law, and Ethics. Routledge.

Chinwokwu, E. C. (2018). An assessment of the relationship between private security companies and police crime prevention in Lagos Metropolis, Nigeria. International Journal of Police Science \& Management, 20(1), 80-93.

Clarke, R. (2017). Situational Crime Prevention: Theoretical Background and Current Practice. In D. Simpson, V. Jensen \& A. Rubing (Ed.), The City between Freedom and Security (pp. 84-113). Berlin, Boston: Birkhäuser.

Creswell and Creswell, A. (2016). Social research methods. Oxford university press.

Creswell, J. W. (2014). A concise introduction to mixed methods research. SAGE publications.

Creswell, J. W., \& Creswell, J. D. (2017). Research design: Qualitative, quantitative, and mixed methods approaches. Sage publications.

Dambazau, A., \& Rtd, L. G. (2013). Overcoming Nigeria's security challenges. Lecture given at the Eleventh Convocation Ceremonies of Igbinedion University, Okada, Nigeria, 28.

Diphoorn, T. (2016). "Surveillance of the Surveillers": Regulation of the Private Security Industry in South Africa and Kenya. African studies review, 59(2), 161-182.

Fischer, R., Edward Halibozek, M. B. A., \& Walters, D. (2012). Introduction to security. ButterworthHeinemann.

Freilich, J. D., \& Newman, G. R. (2017). Situational crime prevention. In Oxford research encyclopedia of criminology and criminal justice.

Gareis, S. B. (2012). The united nations. Macmillan International Higher Education.

Garland, D. (2012). The culture of control: Crime and social order in contemporary society. University of Chicago Press.

George, B., \& Kimber, S. (2014). The history of private security and its impact on the modern security sector. In The Handbook of Security (pp. 21-40). Palgrave Macmillan, London.

Gill, M. (2015). Senior police officers' perspectives on private security: sceptics, pragmatists and embracers. Policing and society, 25(3), 276-293.

Githimi, S., Bor, E., \& Appolos, M. (2017). How the availability of private security services assist in crime control in Nairobi County, Kenya. Global Journal of Arts, Humanities and Social Sciences, 5(1), 51-61.

Hollis-Peel, M. E., Reynald, D. M., Van Bavel, M., Elffers, H., \& Welsh, B. C. (2011). Guardianship for crime prevention: A critical review of the literature. Crime, law and social change, 56(1), 53-70.

Huisman, W., \& Van Erp, J. (2013). Opportunities for environmental crime: A test of situational crime prevention theory. British Journal of Criminology, 53(6), 1178-1200.

Karuri, J. G., \& Muna, W. (2019). Effects of community policing on crime prevention in Kakamega County, Kenya. International Academic Journal of Law and Society, 1(2), 312-327.

Oanda, V. T. (2013). Challenges of strategy implementation in Private Security Companies in Kenya (Doctoral 
dissertation, University of Nairobi).

Ott, R. L., \& Longnecker, M. T. (2015). An introduction to statistical methods and data analysis. Cengage Learning.

Park, D. K., \& Kim, T. M. (2011). Mutual Cooperation between USA Police and Private Security: Actual Status and Meaning. Korean Security Journal, (28), 207-228.

Reynald, D. M., \& LeClerc, B. (Eds.). (2017). The Future of Rational Choice for Crime Prevention. Routledge.

Riunga, D. (2019). Armed Private Security Firms And Counter Terrorism In Kenya (Doctoral dissertation, University of Nairobi).

Sutton, A., Cherney, A., \& White, R. (2014). Crime prevention: Principles, perspectives and practices. Cambridge University Press.

Thuranira, N., \& Munanye, F. L. (2013). Collaboration between public and private security in Kenya. International Journal of Social Sciences and Entrepreneurship, 1(3), 303-318.

Uzuegbu-Wilson, E. (2020). Partnership between the Police and Private Security Services on Crime Prevention and Control in Nigeria: An Empirical Analysis. Available at SSRN 3690755.

Van Steden, R., van Caem, B., \& Boutellier, H. (2011). The 'hidden strength'of active citizenship: The involvement of local residents in public safety projects. Criminology \& Criminal Justice, 11(5), 433-450.

Wakhu, F. M. (2012). Factors leading to the influx of street children in Kakamega (unpublished Ph. D thesis). Kenyatta University, Kenya.

Wilson, J. Q., \& Petersilia, J. (Eds.). (2010). Crime and public policy. Oxford University Press. 